Jurdimas (Jurnal Pengabdian Ke pada Masyarakat) Royal

Vol. 3 No. 2, Juli 2020, hlm. 135 - 140

DOI: https://doi.org/10.33330/jurdimas.v3i2.485

ISSN 2622-3813 (Online)

Available online at https://jurnal.stmikroyal.ac.id/index.php/jurdimas

\title{
PELATIHAN PENERAPAN SIMULAH 1.0 BERBASIS WEB BAGI GURU SMK NEGERI 1 KISARAN
}

\author{
Wiwin Handoko ${ }^{1}$, Muhammad Iqbal ${ }^{1}$, Zulfan Efendi ${ }^{1 *}$ \\ ${ }^{1}$ Program Studi Sistem Informasi, STMIK Royal Kisaran \\ email: zulfan808@gmail.com
}

\begin{abstract}
Daily Exam is an Assessment to carried out each time for this learning. The Implementation of Daily exam in SMK is still done manually and used the question and answer papers, so that the process couldn't be received and not efficient for this time, as the procedure of the students' exams. This way, that was very difficult for teachers. The program of SIMULAH 1.0 is a web-based information system that we used to manage the exam. Management includes the question management for a teacher, subject, and assessment. This training was conducted to help teachers of SMK Negeri 1 Kisaran to implement this program and more efficient as the daily exam by using the information system.
\end{abstract}

Keywords: daily exam; training; simulah 1.0

Abstrak: Ulangan Harian adalah Penilaian yang dilakukan setiap menyelesaikan satu muatan pembelajaran. Pelaksanaan Ulangan Harian di SMK Negeri 1 kisaran masih dilakukan dilakukan secara manual menggunakan kertas soal dan jawaban sehingga dalam proses pelaksanaannya belum efisien baik dalam waktu maupun pemeriksaan hasil ujian peserta didik tersebut. Hal ini tentunya sangat menyulitkan bagi guru. SIMULAH 1.0 merupakan sistem informasi berbasis web yang digunakan mengelola ujian tersebut. Pengelolaannya meliputi manajemen soal, guru, mata pelajaran dan penilaian. Pelatihan ini dilakukan untuk membantu guru SMK Negeri 1 Kisaran dalam pelaksanaan ujian ulangan harian yang lebih efisien dengan memanfaatkan sebuah sistem informasi.

Kata kunci: ulangan harian; pelatihan; simulah 1.0

\section{PENDAHULUAN}

Ujian merupakan sebuah aktifitas yang bertujuan untuk mengevaluasi hasil belajar siswa dalam dunia pendidikan, yang selanjutnya ujian tersebut diharapkan dapat mengukur taraf pencapaian suatu tujuan pengejaran baik dari siswa/siswi sebagai peserta didik (Utomo, 2017). Seiring dengan berkembangnya teknologi, sistem ujian manual atau konvensional secara bertahap ingin diubah menjadi sistem ujian berbasis teknologi informasi (Saraswati \& Putra, 2015).

Secara umum ada 3 pemanfaatan teknologi informasi atau instruksional computer dan internet untuk pendidikan dan pembelajaran. Pertama, Learning about computers and the internet, yaitu komputer dapat dijadikan sebagai objek pembelajaran, misalnya ilmu Komputer (computer science). Kedua, Learning with computers and the internet, yaitu teknologi informasi memfasilitasi pembelajaran sesuai dengan kurikulum 
Available online at https://jurnal.stmikroyal.ac.id/index.php/jurdimas

yang berlaku di sekolah. Ketiga, Learning through computers and the internet, yaitu mengintegrasikan pengembangan keterampilanketerampilan berbasis teknologi informasi dengan aplikasi-aplikasi dalam kurikulum (Putra, 2019).

SMK Negeri 1 Kisaran merupakan sekolah yang telah memiliki fasilitas teknologi informasi yaitu jaringan komputer dan internet yang baik. namun hal tersebut belum dimanfaatkan secara optimal dan efektif hal ini terbukti dengan Pelaksanaan Ujian terutama Ulangan Harian. Ulangan harian adalah kegiatan yang dilakukan secara periodik untuk mengukur pencapaian kompetensi peserta didik setelah menyelesaikan satu kompetensi dasar (KD) atau lebih (Magdalena, 2015). Pelaksanaan ujian ini masih dilakukan berbasis manual atau menggunakan kertas sehingga guru harus menambah jam kerja untuk menyusun soal, penggandaan soal, mengawasi ujian, memeriksa hasil ujian hingga proses penilaian.

Berdasarkan uraian yang telah dijelaskan, maka Pengabdian Masyarakat ini dilaksanakan untuk memberikan pelatihan kepada guru-guru SMK Negeri 1 Kisaran bagaimana membuat sebuah manajemen Ulangan Harian yang baik dengan bantuan sebuah Sistem Informasi yang telah kami buat.

\section{METODE}

Kegiatan ini dilaksanakan pada hari Jumat tanggal 16 Agustus 2019. Kegiatan pengabdian kepada masyarakat ini dilakukan oleh Tim Dosen. Tim pengabdian terdiri dari 3 orang dosen. Tugas masing-masingnya, yaitu 1 orang menjadi Narasumber 1, 1 orang menjadi
Narasumber 2, dan 1 orang menjadi instruktur peserta dalam praktek. Materi yang disampaikan adalah Pengenalan SIMULAH 1.0 oleh Narasumber 1 kemudian dilanjutkan dengan Teknik Penggunaan SIMULAH 1.0 oleh Narasumber 2 dibantu instruktur peserta dalam prakteknya.

Metode pelaksanaannya yaitu memberikan pelatihan kepada guru SMK Negeri 1 Kisaran bagaimana Teknis Penggunaan SIMULAH 1.0 (Sistem Informasi Manajemen Ujian Ulangan Harian) sekaligus praktikum dan Guru juga dapat bertanya melakukan sesi tanya jawab kepada narasumber.

\section{PEMBAHASAN}

\section{Penggunaan Sistem Informasi Ulangan Harian (SIMULAH)}

\section{Akun Guru}

1. Login

Setiap guru yang akan menggunakan sistem wajib melakukan login. Login dapat dilakukan dengan mengunjungi alamat/ url web yaitu:

Guru memilih tab "Login Guru" dan mulai memasukan username dan password yang diperoleh dari operator. Apabila Guru kehilangan password dapat menghubungi operator untuk mengganti password yang baru.

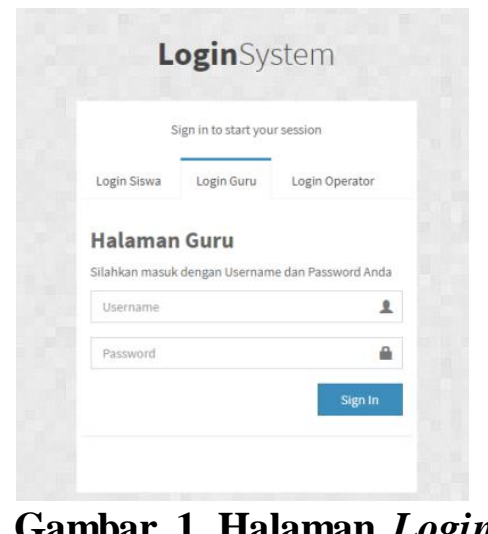

Gambar 1. Halaman Login 
Available online athttps:/jurnal.stmikroyal.ac.id/index.php/jurdimas

\section{Halaman Dashboard}

Halaman dashboard merupakan halaman awal setelah guru berhasil melalukan login. Pada halaman ini terdapat beberapa menu, yaitu:

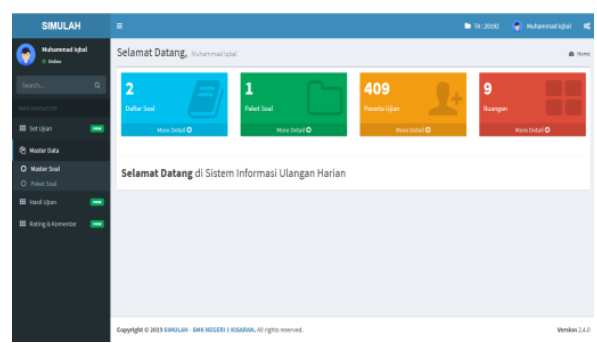

\section{Gambar 2. Halaman Dashboard Guru}

\section{Set Ujian}

Halaman ini berfungsi sebagai pengaturan awal sebelum ujian dimulai. Guru dapat menentukan nama kelas/ruangan, nama pengawas 1 dan 2 dan memilih paket soal, mengatur sesi dan jadwal ujian. Cara untuk setting ujian

Pertama, Klik kiri pada menu sebelah kiri terdapat menu Set Ujian, maka akan tampil seperti gambar di bawah ini:

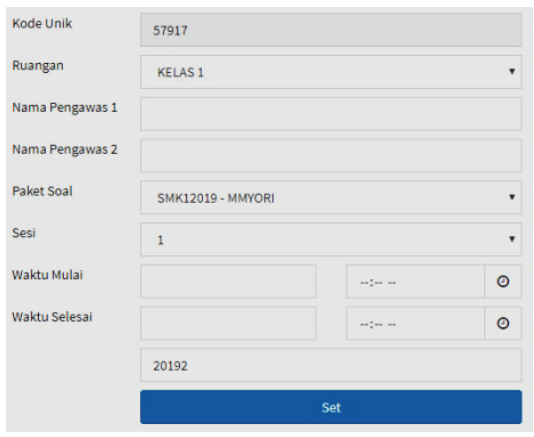

\section{Gambar 3. Tampilan Set Ujian}

Langkah kedua, Pada kolom Ruangan, klik simbol panah ke bawah untuk menyesuaikan ruangan. Data Ruangan diperoleh dari operator. Ketiga, Silahkan ini kolom pengawas 1 dan 2. Kemudian pilih paket soal yang telah didaftarkan. Keempat, Isi kolom sesi apabila dibutuhkan.
Kelima, Setting waktu mulai dan berakhirnya ujian, mulai dari tanggal dan jam untuk ujian. Keenam, Kolom "20192" merupakan kode tahun ajaran yang berlaku. Pastikan data yang tersimpan berdasarkan tahun ajaran yang telah ditentukan oleh operator. Dan yang terakhir Klik Set.

Jadwal ujian ini terdiri dari waktu awal (mulai) dan waktu selesai. Siswa / Peserta ujian dapat memulai ujian apabila telah masuk waktu dimulai dan Siswa / Peserta akan keluar dari sistem apabila waktu mulai berakhir.

\section{Master Data}

- Master Soal

Merupakan kumpulan / bank dari berbagai soal yang ditampilkan berdasarkan guru yang melakukan login.

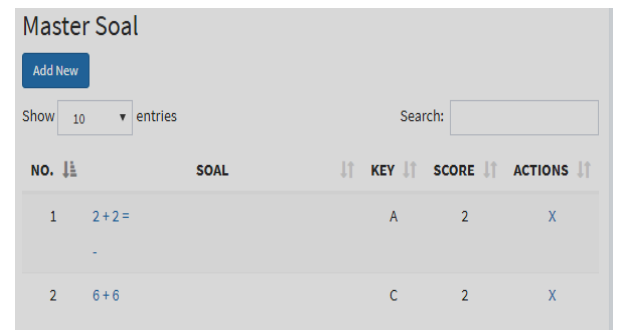

Gambar 4. Tampilan Master Soal

Cara untuk menambahkan soal pada Master Soal:

Pertama, Klik "Add New", setelah itu akan tampil halaman input soal seperti gambar berikut:

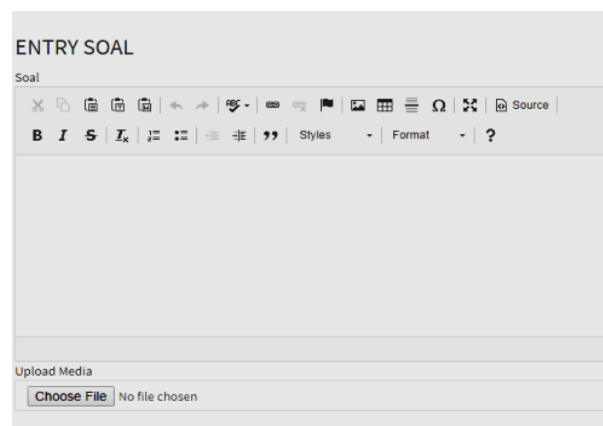

Gambar 5. Halaman input soal 
Available online athttps:/jurnal.stmikroyal.ac.id/index.php/jurdimas

Kedua, Jika membutuhkan soal dalam bentuk gambar, caranya klik button "Choose File" / "Browse" / "Telusuri" / "Pilih File". Cari dimana posisi gambar tersimpan. Ketiga, Scroll ke bawah untuk mengisi pilihan A sampai D. Keempat Sesuaikan kunci jawaban dan Score per soal. Dan yang kelima, Klik button "Tambah Soal".

\section{- Paket Soal}

Paket soal memiliki fungsi sebagai folder yang memuat beberapa soal. Paket soal yang ditampilkan pada halaman dashboard guru hanya paket yang telah didaftarkan oleh guru tersebut.

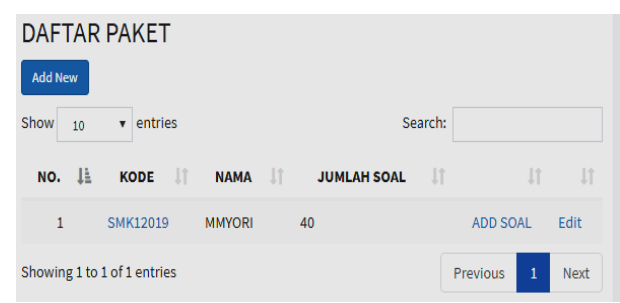

Gambar 6. Tampilan Halaman Daftar Paket

Pada halaman daftar paket terdapat beberapa link:

KODE : berfungsi untuk menampilkan soal berdasarkan paket

ADD SOAL : berfungsi untuk menambahkan paket berdasarkan paket yang dipilih

EDIT : berfungsi untuk mengubah data paket (bukan soal).

\section{Hasil Ujian}

Hasil Ujian merupakan halaman yang menyajikan data hasil ujian yang dilakukan siswa/peserta yang dikelompokkan berdasarkan kode.
Kode tersebut diperoleh dari menu Set Ujian.

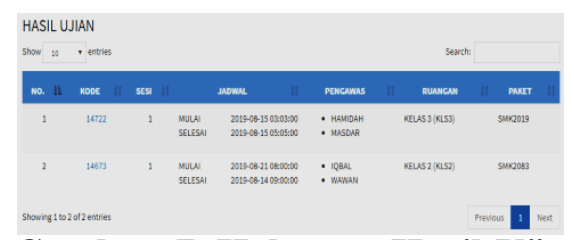

Gambar 7. Halaman Hasil Ujian

Pada halaman ini terdapat sebuah link "kode". Apabila link tersebut diklik maka akan menampilkan jumlah siswa yang ikut ujian beserta akumulasi benar dan salah.

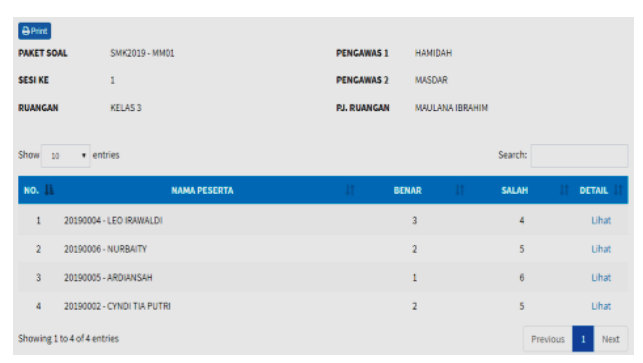

\section{Gambar 8. Halaman Detail Peserta Ujian}

Pada halaman hasil tersebut dapat dilihat detail hasil jawaban siswa/peserta melalui link "Detail".

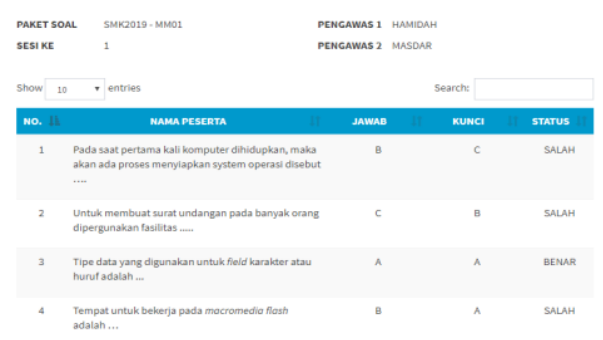

\section{Gambar 9. Detail Jawaban Per Sis wa / Peserta Ujian}

\section{Rating dan Komentar}

Halaman Rating dan Komentar merupakan halaman yang menyajikan penilaian siswa/peserta terkait aplikasi maupun pengalaman mereka selama ujian. Setiap guru dapat melihat semua komentar dan penilaian dari peserta. 
Jurdimas (Jurnal Pengabdian Kepada Masyarakat) Royal

Vol. 3 No. 2, Juli 2020, hlm. 135 - 140

DOI: https://doi.org/10.33330/jurdimas.v3i2.485

Available online athttps:/jurnal.stmikroyal.ac.id/index.php/jurdimas

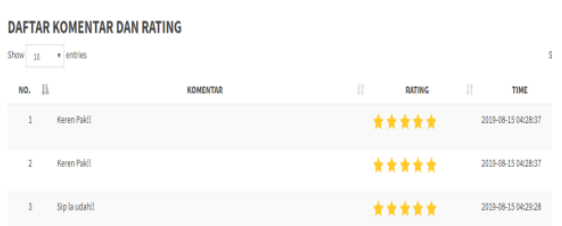

\section{Gambar 10. Halaman Rating dan Komentar}

\section{Logout ( Keluar dari sistem )}

Untuk mengakhiri sesi guru dari sistem. Guru dapat melakukan SignOut melalui menu di sudut kanan atas, seperti gambar berikut:

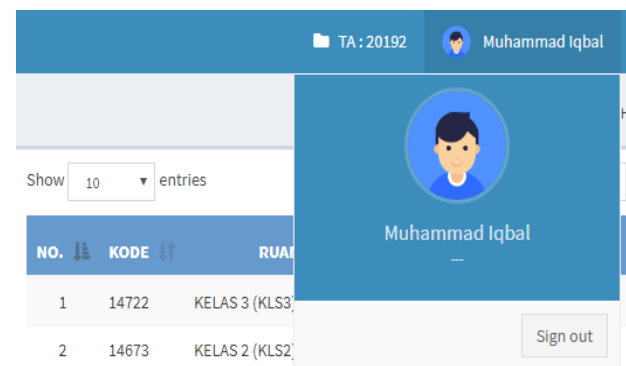

\section{Gambar 11. Halaman Logout /} Sign Out

Berikut beberapa dokumentasi kegiatan Pengabdian kepada Masyarakat berupa pelatihan di SMK Negeri 1 Kisaran:

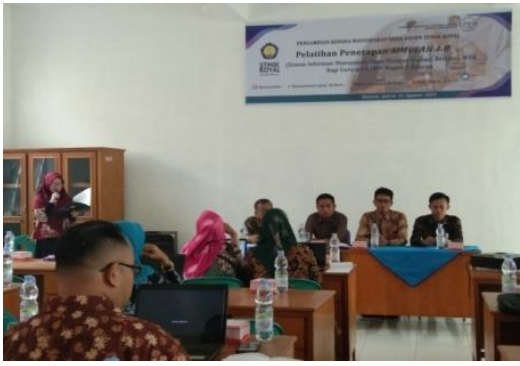

Gambar 12. Acara Pembukaan

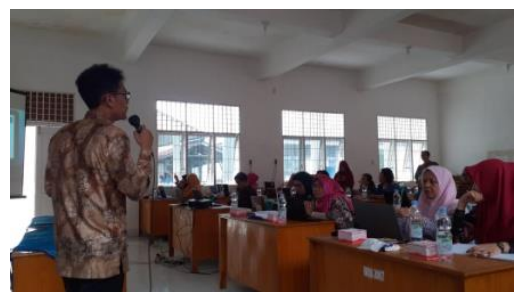

Gambar 13. Penyampaian Materi

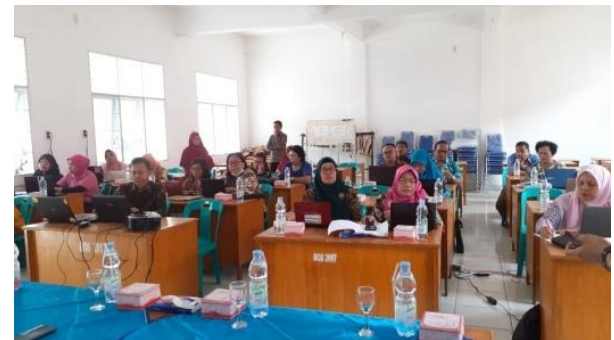

Gambar 14. Peserta Pelatihan

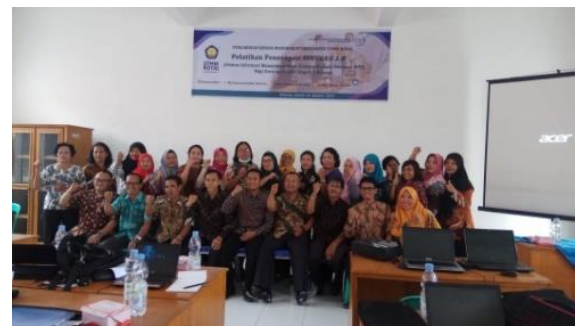

Gambar 15. Foto Bersama

\section{SIMPULAN}

Simpulan dari Kegiatan Pengabdian Masyarakat ini adalah Guru dan Staf Tata Usaha dapat memahami cara kerja dan penggunaan SIMULAH 1.0 dengan baik dan guru sangat terbantu dengan adanya sistem informasi ini karena hasil ulangan harian siswa/i dapat diketahui secara cepat dan tepat.

\section{DAFTAR PUSTAKA}

Diarmansyah Batubara, M., \& Indra, E. (2018). Perencanaan dan Pembuatan Aplikasi Pengerjaan Ujian Nasional Tingkat SMP Berbasis Android. QUERY Jurnal Sistem Informasi, 2(Oktober), 47-57.

Magdalena, L., Nurkholifah, A. A., \& Hatta, M. (2015). Aplikasi Ulangan Harian Menggunakan Systematic Random Sampling Berbasis Web Studi Kasus: Smkn 1 Bulakamba Brebes. JURNAL DIGIT, 5(2), 133145. 
Available online athttps:/jurnal.stmikroyal.ac.id/index.php/jurdimas

Mubarok, A., \& Kurniawan, M. C. (2016). Aplikasi Ujian Online Pada Smk Ma'Arif Bandung Berbasis Web. Jurnal Informatika, 2(1), 332344. https://doi.org/10.31311/ji.v2i1.89

Nugroho, A. S. (2019). Pengembangan Ulangan Berbasis Android Menggunakan Aplikasi Google Form. Jurnal SITECH: Sistem Informasi Dan Teknologi, 1(2), 8994.

https://doi.org/10.24176/sitech.v1i2. 2758

Putra, R. L., Maulana, A., \& Iriani, T. (2019). Evaluasi Program Pelaksanaan Ujian Online dengan Menggunakan Learning Management System Moodle Berbasis Android di SMK Negeri 1 Jakarta. Jurnal Pendidikan Teknik Sipil, $\quad 8(1), \quad 48-54$. https://doi.org/https://doi.org/10.210 09/jpensil.v8i1.8483

Reja, I. D., \& Nganggo, D. R. (2018). MENINGKATKAN KUALITAS HASIL UJIAN MENGGUNAKAN APLIKASI UJIAN ONLINE ( STUDI KASUS SEKOLAH MENENGAH KEJURUAN ( SMK ) St. YOHANES XXIII MAUMERE ). Seminar Nasional Sains Dan Teknologi Fakultas
Teknik Universitas Muhammadiyah Jakarta, 1-5.

Ridwan Prasetya Utomo, Arief Budiman, \& Joko Triono. (2017). Aplikasi Ujian Online Masuk Universitas Merdeka Madiun Berbasis Android. Pilar Teknologi, 2(March).

Saraswati, N. W. S., \& Putra, D. M. D. U. (2015). Sistem Ujian Online Berbasis Website. S@Cies, 6(1), 21-30.

https://doi.org/10.31598/sacies.v6il. 78

Sitanggang, A. L., Hati Loi, M., \& Indra, E. (2019). RANCANG BANGUN APLIKASI SISTEM UJIAN SARINGAN MASUK SMA BERBASIS ANDROID (Studi Kasus SMA Amir Hamzah Medan). Jurnal Sistem Informasi Ilmu Komputer Prima (JUSIKOM PRIMA), 2(2).

Susilowati, S., \& Hidayat, T. (2018). Rancang Bangun Sistem Informasi Ujian Online ( Studi Kasus Pada SMAN 58 Jakarta ). Jurnal Teknik Komputer, 4(1), 30-36. https://ejournal.bsi.ac.id/ejurnal/inde x.php/jtk/article/viewFile/2474/1902 